\title{
2. Troubled Masculinities and Gender Violence in Melanesia
}

\author{
Laura Zimmer-Tamakoshi
}

\section{Abstract}

The subject of this chapter is how young men's marital and economic prospects, their conflicts with older men, and their engagement with modernity and kastam are related to gender violence in Melanesia. ${ }^{1}$ I also examine what young women think and how women of different ages make the most of increasingly unequal economic and marital circumstances and I argue for a shift from the use of the term 'gender violence' to 'engendered violence', a more encompassing term allowing for complex explanations and findings. Drawing on the accounts of early missionaries, oral and written histories and thirty years of my own research and writing about the Gende of southern Madang Province and elsewhere in Papua New Guinea, I build a profound case against any simple understanding of gender violence. The Gende case demands that researchers focus on both men's uneasy confrontation with modernity and kastam and women's efforts at achieving a semblance of agency and personal security in the midst of deeply challenging economic, cultural and social changes.

\section{Introduction}

Violence against females (often referred to as 'gender violence') is the most common form of interpersonal violence in Melanesia. In Papua New Guinea (PNG), such violence is prevalent in urban and rural households and reported rates of rape and sexual assault against women and girls exceed those in many industrial and developing countries. Equating 'gender violence' with violence against females, however, excludes from discussion male victims of domestic or sexual violence. It also underplays the complexities of Melanesian gender relations and ignores men's uneasy confrontations with modernity and kastam (resulting in 'embattled masculinities' Jolly 2000), men's status insecurities amidst some women's new agency, and the changing structures and contexts (e.g. kinship, age and gender) that promote violence against females and males.

1 We are using the Tok Pisin orthography for kastam. Kastom is more common in Solomon Islands pidgin and the Bislama of Vanuatu. 
While Melanesia is renowned for its diverse concepts of masculine social, bodily and sexual development (Knauft 1999), there are few studies on how changing masculinities play into gender violence.

Troubled masculinity is a recurring theme in my research. In a 1984 paper I explored the economic and cultural bases of male identity crises among the Gende in PNG (Zimmer 1984). Then as now, uncertain development and inequality spurred by migration and urban remittances put pressure on Gende exchange relations, resulting in the bachelorisation of Gende society (Zimmer-Tamakoshi 1993a), domestic and intergenerational violence as older persons favour wealthier men as exchange partners and sons-in-law (Zimmer 1990a; ZimmerTamakoshi 1993a), and often deadly conflicts over land and the interpretation of kastam (Zimmer-Tamakoshi 1997a, 2001). While unemployed wives of migrants may suffer an imbalance of power in their affinal and other exchange relationships, many Gende women enhance their influence and personal security as the 'owners' of large pig herds, as the thrifty (and indispensable) wives of less prosperous migrants or as successful businesswomen (Zimmer-Tamakoshi 1993a, 1996, 1997a). A few earn enough to delay marriage or forego bride price, asserting an independence that does not sit well with men or women's families (Rosi and Zimmer-Tamakoshi 1993).

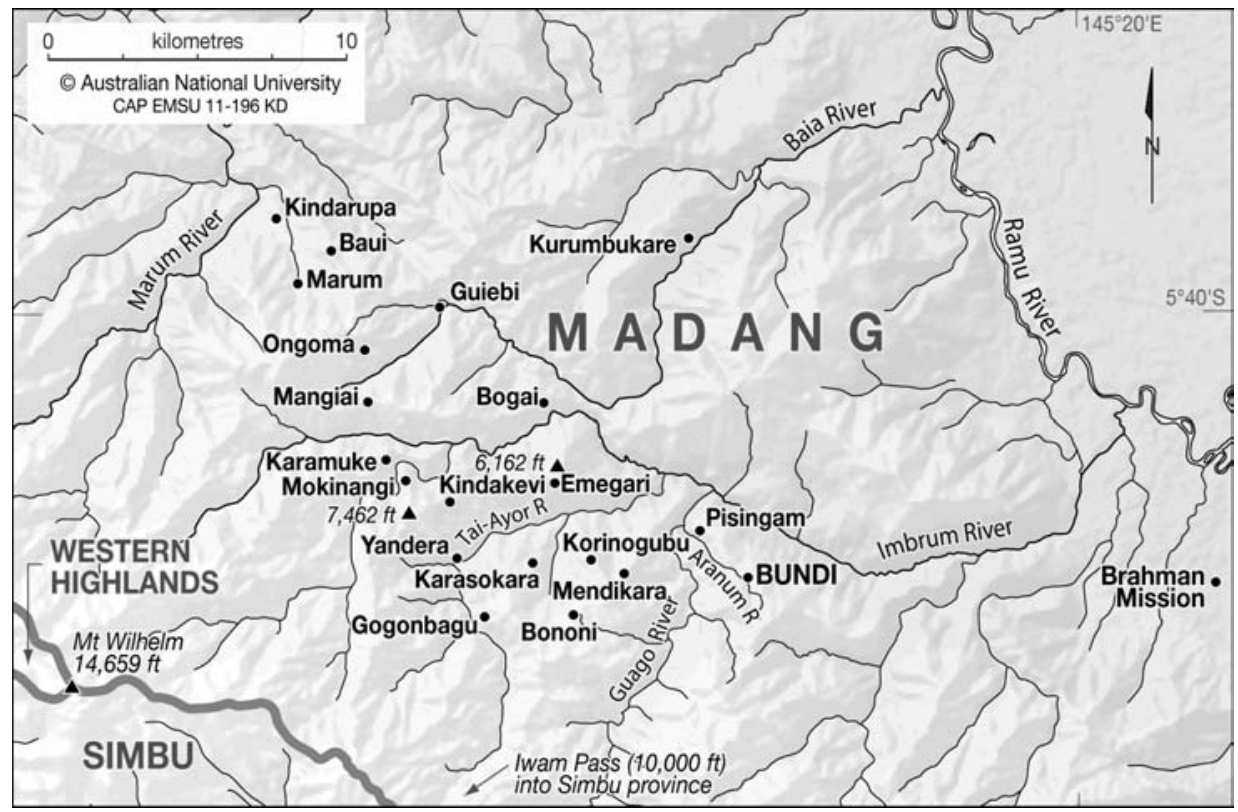

Map 2. Gende villages are located in a mountainous region of the Madang Province which borders Simbu Province. Map production by Education and Multimedia Services, College of Asia and the Pacific, The Australian National University. 
In recent years, two large mining ventures within the bounds of Gende territory promise to usher in prosperity and bolster threatened masculinities. The Ramu Nickel Project, however, is already generating a wave of second marriages (and domestic violence) as older men bank on future compensation, and a storm of ancestral gerrymandering as men and women negotiate over who are legitimate landowners, often leaving younger (and unmarried) men out of the negotiations (Zimmer-Tamakoshi 2001, 2006). In Spring 2007, I returned to PNG to investigate further how the Gende are responding to expected reversals of fortune, focusing on (1) emergent and competing masculinities as older and younger men enact their manhood in the supercharged atmosphere of large-scale mining operations and (2) the impacts of changing masculinities on women's strategies and wellbeing.

I begin this chapter with several recent dramatic twists in Gende men and women's situations and prospects - brought on by the rapid intrusion of two international mining operations. I then present an overview of theoretical works on gender violence in Melanesia followed by an account of troubled masculinities among the Gende over the course of eighty years and an analysis of young men's violence and contradictory experiences of power. Throughout, it is apparent that Gende gender relations have always been fluid and complex. A lengthy period of bachelorisation and poor local prospects during the Gende's post-contact period was followed by an explosion of opportunity for young men, especially for those living in Yandera village and other areas of interest to Marengo Mining, and in Gende villages closer to the Ramu Nickel prospect at Kurumbukare (in Gende territory). During the same time period Gende women have experienced their own ups and downs, often in contrast to men's experience, with balanced gender relations becoming more a rarity than a norm in some Gende locales.

Throughout the chapter, I demonstrate how the agency of both males and females is encompassed in matrices of social relations and obligation. I show how failures of young men and women to live up to their elders' expectations and demands negatively affect their relations with one another. And I argue that the use of the term 'engendered violence' makes more sense than 'gender violence' when explaining a young husband's violence against a wife for whom his family paid a large bride price and from whom they have not received the expected redemption of the bride price known as tupoi; or when a younger man attacks an older man who interferes with the younger man's marital prospects by hoarding the benefits of land 'ownership' and compensation for his own ends and failing to pay bride price for a wife for the younger man in a society in which marriage is still the only road to social adulthood.

None of what I argue is intended to excuse violence of any kind. In my conclusion I elaborate on how looking at gender violence in broader ways may 
make it possible to find solutions to male violence. By putting gender back into its larger socio-cultural contexts, I avoid separating issues involving women and children - too often relegated to the domestic sphere (e.g. 'domestic violence') from ones involving the entire community such as tribal violence, intergenerational and class conflicts over kastam and modernity, and globalisation. Only by unravelling the matrices of engendered relations that men and women live and act in - such as relations between older and younger men and how these impact both older and younger men's access to and relations with women and power - can we truly understand male violence (or for that matter, women's acts of violence and rebellion).

\section{Twists and turns in the road to development: The new polygynists and 'merry' widows of Yandera}

In 2007 I returned twice to PNG after a hiatus of nearly seven years. My objectives were threefold: to update my ongoing research on troubled masculinities among Gende males; to investigate a Gende woman's run for the Usino-Bundi Open in the National elections; and to design and carry out a census in Yandera village in southern Madang Province, the centre of a new mining prospect run by Marengo Mining of Australia. Collecting 227 eleven-page household interviews with the help of four graduates of Madang's Divine Word University and spending four and a half months with Gende men and women in Yandera, Madang and in between, I left 'the field' with a mountain of data and some startling observations on what appeared to be a seismic shift in young men's marital prospects (at least in Yandera) and some surprising developments in women's situations and attitudes.

After a long history of bachelorisation and its attendant social frustrations for many males in Yandera and other Gende settlements, suddenly there was plentiful and well-paid work with the arrival of Marengo in 2005 and the startup of exploratory drilling and other operations. Those working for Marengo could now afford the larger bride prices that had kept many out of the marriage market in decades past. There were virtually no bachelors over the age of twentyfour in Yandera. What startled me most, however, was not that men in Yandera had apparently gained an edge in the marriage market, but rather the upsurge in polygyny, not among older men but among very young men. The 'new polygyny' along with the disturbing fact that there were few older men over the age of fifty still alive in Yandera were linked with an abundance of strong and seemingly merry widows. I say 'merry' because the widows were happily 
building up and securing their own high social standing in the community by raising pigs for their deceased husbands' (and other male relatives') funeral and death payments (kwiagi) and their sons' marriage payments.

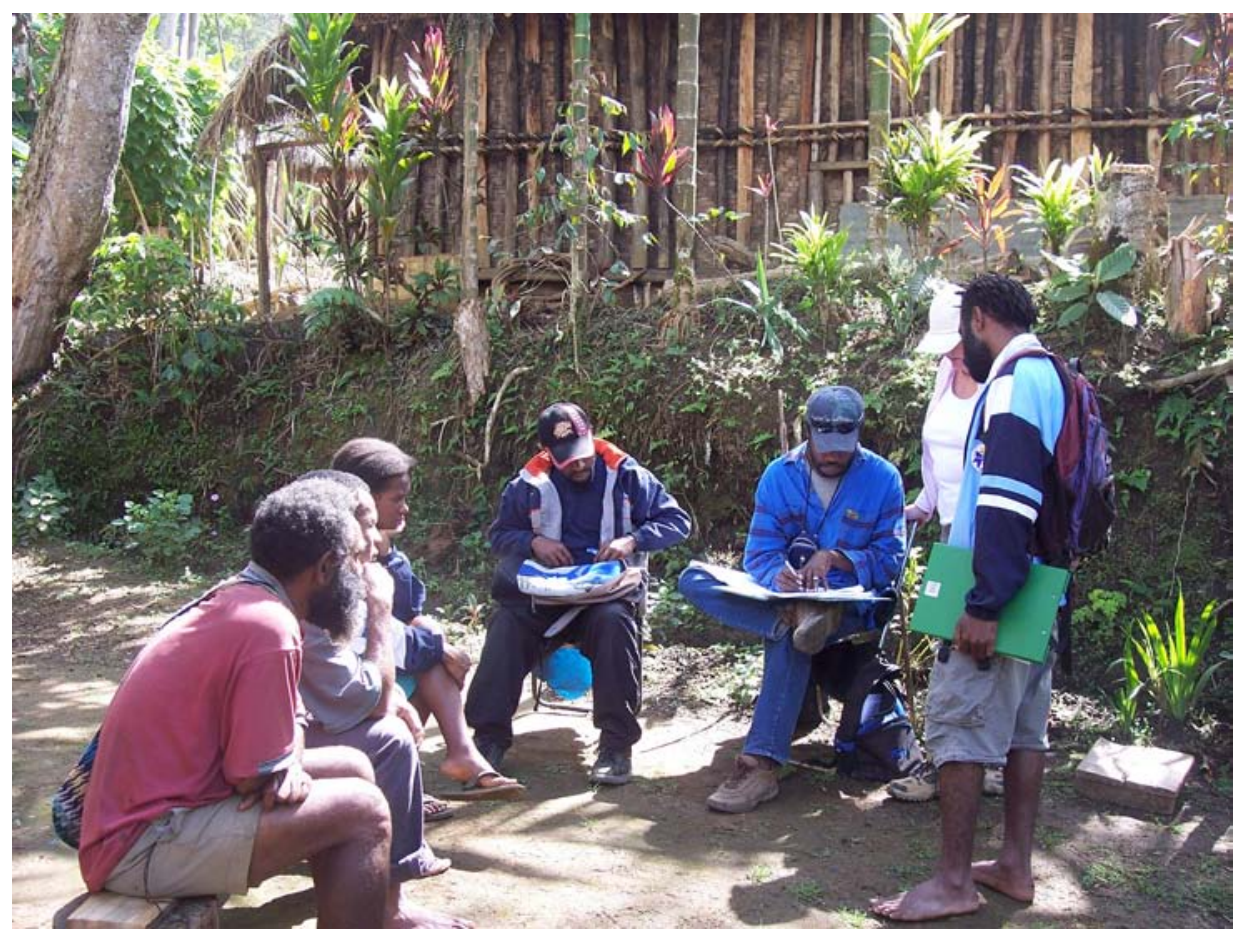

Figure 4. Laura Zimmer-Tamakoshi instructing her field assistants on how to do the Yandera household survey, 2007.

Photo courtesy of Laura Zimmer-Tamakoshi.

Clearly, the money earned by working at Marengo was being turned into matrimonial capital and it appeared that young polygynists were replicating the practice of Big Men of yore by marrying two or three wives: one from Yandera or some other Gende village along with one or more from nearby Simbu and Ramu peoples. In such a manner past Big Men developed large networks of exchange partners along an ancient trade route connecting the north coast with the central highlands. What the new polygynists were up to, however, required several more seasons of fieldwork and reflection to figure out, as did the question of why pigs continue to be a critical part of exchanges when their cash equivalents are known down to the last toea (about half a cent) and pigs are less readily accessible to men who work in town or whose wives have not accompanied them back to the village. 


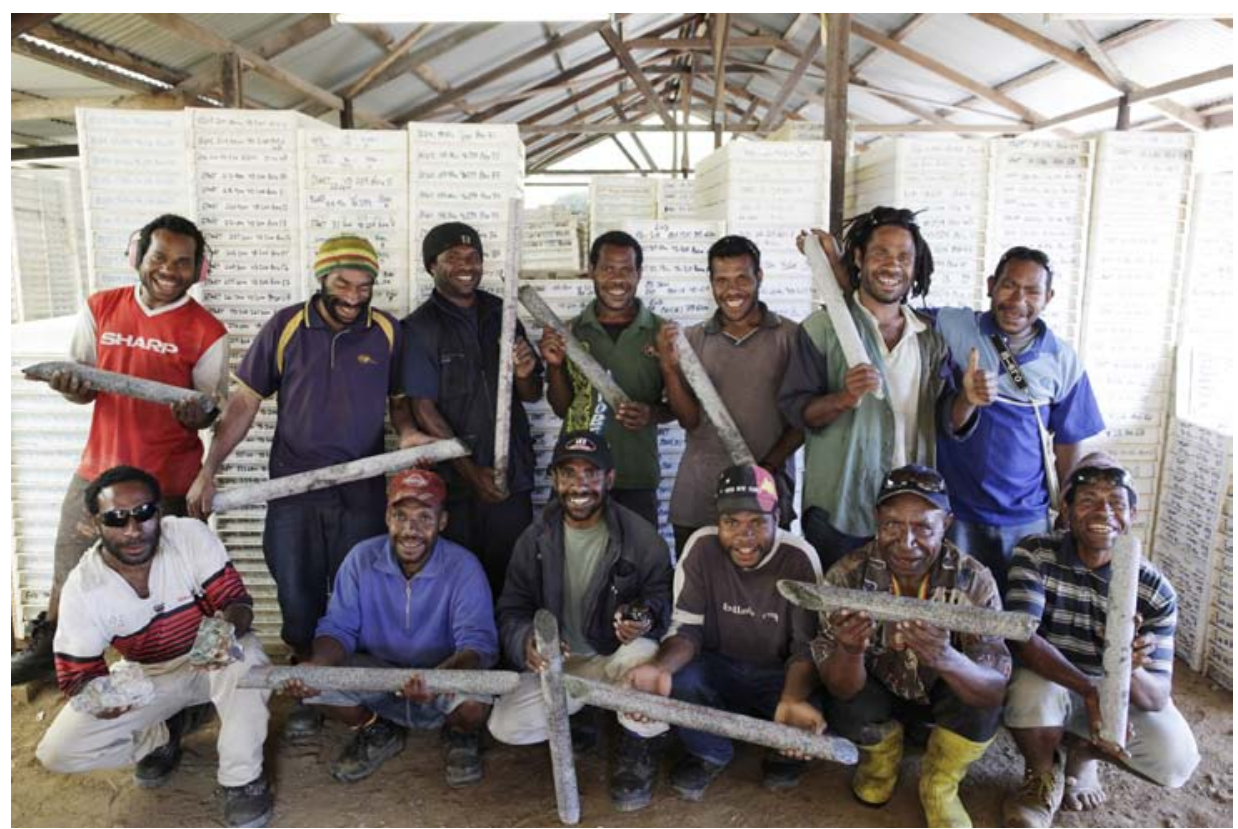

Figure 5. Yandera men working at Marengo's core shed, 2009.

Photograph by Hugh Brown, courtesy of Marengo Mining Ltd.

The situation I confronted in Yandera in 2007 seemed to bear little resemblance to what I had observed at Ramu Nickel in 1995 and 2000. In 1995, there were many young bachelors at Ramu Nickel's prospect at Kurumbukare and they and their mothers were in constant and sometimes deadly conflict with the older men who were using land compensation payments (and the likelihood of larger payments once Ramu Nickel took off) to acquire second and third wives (wisely keeping them in town away from angry first wives). Based on data collected in 2007 and subsequently, however, some of the younger workers at Ramu Nickel are now also acquiring wives (although not two or three as in Yandera) as a number of older men have since died of malaria in the mosquito-infected lower hills and swampy plains around the expanding Ramu Nickel projects and in Madang, or succumbed to more suspicious causes associated with accusations of sorcery. In this context, the absence of so many older men in Yandera's population was all the more disturbing as it raised the question of whether or not they too had been killed or driven into an early demise. While my household surveys showed that many of the deceased men had died of natural causes, some had indeed been murdered because they were alleged sorcerers and still others reportedly died of stress related to conflict with wives and children. That the new polygynists and merry widows in Yandera seemed immune to similar accusations of sorcery begged explanation. 
Expanding their area of interest and exploratory drilling in 2008, Marengo requested that I extend my survey/census to include two sets of Gende settlements often referred to by the old Gende clan names 'Gegeru' and 'Karizoko'. Both of these old clans long ago segmented into inter-marrying clans that continue to inhabit the same general locations as formerly: Gegeru villages strung out along steep ridges between Yandera and Kurumbukare (the centre of the Ramu Nickel prospect); Karizoko villages and hamlets across from Yandera on the side of the mountains closer to Madang's border with Simbu Province. What I learned in the months I spent in the field in 2008 strengthened my longstanding argument against any simple understanding of gender violence. ${ }^{2}$

A significant outcome of my analysis of data collected in 2008 is the finding that - at least in the Gende villages surrounding the Ramu Nickel prospectsociability has constricted such that fewer marriages are being made with partners who are not members of one or the other Gegeru clans (the Gende clans with the strongest claims on the land at the Ramu Nickel prospect at Kurumbukare). In the past Gegeru clansmen helped their in-laws in Yandera to fight off attacks by Karizoko and Emegari warriors, providing safe haven for years when the defence failed. This relatively recent constricted sociability is in part explained by Gegeru attempts to keep the benefits of land ownership and work at Kurumbukare and Ramu Nickel to themselves. It is also related to the higher bride prices now being asked by Yandera parents for their daughters' hands in marriage. It turned out that the Gegeru clan villages I surveyed had higher rates of divorce than either Yandera or Karizoko settlements. Many of the

2 Papua New Guinea requires that mining companies and other large resource extraction operations carry out environmental and social impact studies during the feasibility stages of operation. Accordingly, I was hired on several occasions by two different mining companies to do social assessment and census work among the Gende with whom I have carried out anthropological research since 1982. The first was Highlands Gold Limited which hired me to do a genealogical survey of the settlements around the Ramu Nickel prospect at Kurumbukare in 1995. Kurumbukare is located in the forested foothills to the north of the Gende's main villages but within Gende territory. In 2000 I revisited the Ramu Nickel prospect at the behest of the renamed Highlands Pacific Company to assess social changes going on among those living in the vicinity of the mine. The local population had continued to grow exponentially as many Gende left their home villages to move closer to the Ramu Nickel prospect, hoping to find work and gain compensation for the use of their land.

In 2007,2008, 2009, 2010 and 2011 a second mining company-Marengo Mining — hired me to carry out social assessment and census studies in the higher altitude Gende villages that lie within their area of exploration and in areas where the company proposes to build hydro dams, airstrips and other mining infrastructure, should their prospect be approved by the government. Because the studies include every household (including absentees) within the project areas and the interview I devised is eleven pages long, I have assistants to work alongside me in interviewing household heads and family members, mapping settlements and taking photo censuses. Because the company pays for all of this the data base is essentially theirs (although I retain my own copies and rights to write about my findings as well as other research I carry out in tandem with the surveys). After each period of fieldwork I input the data and do an analysis of the quantitative data, writing large reports in which I contextualise the data and which go to the company and, at my request, to the National Research Institute in Port Moresby. The data bases and my reports cover many areas of the Gende's life (e.g. kinship, identity, marriage and residence patterns, house construction, education, use of local resources, work, income sources, nutrition and health) and form an important baseline for future comparative studies assessing various impacts of the mine on local populations. 
divorced men and women had shed non-Gegeru partners and almost all then married a Gegeru partner. This appeared surprisingly parsimonious given that the Gende in general are very worldly, having migrated to all parts of PNG in the years when local development was sparse. But then, as several newly remarried Gegeru husbands told me: 'the people in Yandera have Marengo now so we don't have to share Ramu [Nickel] with them' and 'They are greedy. If we marry them, they move in and want money from the company [at Ramu Nickel]. I won't let my sister marry a Yandera man' and 'They are trying to steal our land'.

A second interesting finding of the 2008 census is that the Karizoko clans associated with Karasokara village and its nearby hamlets - all bordering on Yandera's territory - are even more heavily intermarried with Simbu peoples than in the past. It turns out that many Karizokos - who like every other Gende clan also suffered a glut of bachelors in years past - eventually acquired wives as a result of their sisters' marriages to Simbu men and, accepting invitations to move to Simbu settlements, married Simbu wives, and helped sisters and sisters' husbands' families raise coffee and other cash crops. On the Simbu side of the mountains, the Simbu are better connected to the Highlands Highway and greater economic opportunities than was the case - until very recentlyfor the Gende.

This tactic of the Karizokos has had some 'alarming' results as Marengo's drilling on Karasokara territory has generated a tidal wave of returning Karizoko men and women anxious to impress their claims to land on both the company and those villagers who remained 'at home'. Never before had a mining company shown interest beyond the immediate vicinity of Yandera's territory and Karizoko peoples have even fewer claims to land at the Ramu Nickel prospect than most Gende, so it was natural for them to try their luck in town or with Simbu neighbours and in-laws. Although Karasokara village has always been deemed to be similar in population to Yandera, the 400-plus household interviews I collected from Karizoko households in 2008 significantly outnumbered the 227 I collected for Yandera and its garden settlements in 2007. The Yandera clans have had decades of mining interest in their lands and time to slough off migrants who failed to maintain their rural option; while people living in Karasokara and other Karizoko clan settlements have not. During the 2008 census, non-residents crowded into Karasokara and its nearby settlements and other absentees sent emissaries to warn residents not to leave out anyone. Nervous old men visited us late into the night with lists of absent sons and daughters and their many Simbu in-laws. More so it would seem than in Yandera or the Gegeru villages, Karizoko men are beholden to sisters and Simbu in-laws for helping them marry and have families.

After finishing the 2008 survey and while I was still in Madang preparing to return to the United States, there was a shocking incident in one of the Gegeru 
villages that reflects just how deadly tensions over land can be. With Gegeru territory near Yandera also suddenly of interest to Marengo, the Madang-based nephews of one Gegeru landowner we had interviewed only weeks before, returned to the village and axed him to death in an argument over their rights to land once owned by their deceased father. They alleged that their uncle was a sorcerer who had caused his brother's death so he could claim his land as well as his own, but it was widely agreed in the village that the young men had never done much for anyone, that their uncle had paid kwiagi (death payment) for their father, and that the young men were greedy and hoping to profit from future land compensation from Marengo. When the youths escaped to Madang, villagers took three women into custody and threatened to bury them alive if the young men did not turn themselves in and pay compensation to bereaved kin. The nervous old Karizoko men undoubtedly feared similar retribution if they failed to include daughters and sisters in the survey/census as being stakeholders who had earned the right to be included (and they did, certainly more than the young Gegeru migrants).

In 2009, I returned twice to Madang to extend my survey/census even further to include yet another ten Gende settlements, some along a proposed easement route that is near the Ramu Nickel prospect and mostly populated by Gegeru clans, and others closer to Karasokara and populated by Gende belonging to Mendi and Nombri clans. While the analysis of the data for the Mendi/Nombri is not yet completed - and I have done yet more research in 2010 and 2011 in Gende and non-Gende locations (along the Ramu and North Coast) - the situations and words of Gende migrants and villagers I interviewed in 2009 and 2010 have contributed many insights to my understanding of the current situation and so shall be included where relevant in my description and analysis of troubled masculinities and engendered violence among the Gende.

\section{Theorising gender violence}

Violence against females - often referred to as gender violence - is the most common form of interpersonal violence in Melanesia (Dinnen 2000). In PNG, violence is prevalent in urban and rural households (Toft 1985, 1986; Toft and Bonnell 1985) and reported rates of sexual assault and rape exceed those in many industrial and developing countries (Zimmer-Tamakoshi 1997e). Most theories about gender violence focus on distorted traditions (Garap 2000), women's weaker political presence (Counts, Brown and Campbell 1992), psychological and economic pressures of development and inequality (Josephides 1993; Bradley 1994), the effects of urban lifestyles (alcohol abuse, reduced social support networks), increased eroticism and sexual conflicts (Rosi and ZimmerTamakoshi 1993; Jenkins 1994), and a renewal of tribal fighting and rapes of 
enemy women (Garap 2000). Also cited are the intersection of urban/elite sexual politics with nationalist and class interests and rhetoric (Hogan 1985; ZimmerTamakoshi 1993b, 1995, 1997e, 2004) and the difficulties experienced by weak states in preventing lawlessness and rampant police violence (Strathern 1993; Dinnen 1996; see also Ch. 7).

Melanesian women activists and scholars agree with most of the above arguments, decrying increasing violence and women's lack of freedom to make their own choices (Molisa 1987, 1989; Billy, Lulei and Sipolo 1983; Billy 2000; Garap 2000; see Zimmer-Tamakoshi 1995). A few western critics, however, caution that adopting western perspectives on what is 'normal' overlooks the fact that 'domestic' and 'sexual violence' are cultural concepts (Borrey 2000) and that some violence is accepted in many Melanesian societies (O'Collins 2000). A perhaps more compelling criticism is that equating 'gender violence' with violence against females excludes from discussion male victims of domestic and sexual violence (Coursen-Neff 2005). Also ignored are men's uneasy confrontations with modernity and kastam resulting in 'embattled masculinities' (Jolly 2000: 312), men's status insecurities amidst some women's new agency, and the changing structures and contexts (such as kinship, age and gender) that may promote violence against females and males. Both Margaret Jolly (1994, 1997, 2000) and Martha Macintyre (2000 and Ch. 8) have argued against simplistic models of changing gender relations and identities, citing the diversity and fluidity of women's situations and the multiple trajectories women take in efforts to achieve a desirable status within changing contexts.

In this chapter, I explore in more depth Jolly's notion of 'embattled' oras befits the Gende case, 'troubled masculinities' - in Melanesia and how changing masculinities play into various forms of engendered violence. I am especially interested in exploring a particular aspect of men's violence, that sociologist Michael Kaufman calls the 'fourth $\mathrm{P}^{\prime}$ or paradox of men's privilege and power (1994, 1999). In 'The 7 P's of Men's Violence' (1999), Kaufman wrote that among the paradoxes of patriarchal power are what he has called 'men's contradictory experiences of power' (1994). In the context of troubled masculinities in Melanesia, I argue that such contradictory experiences include most young men's abject lack of control over the resources they need to achieve both local and global ideals of masculine social and individual power. Today, some of these necessary resources include higher education, being recognised as legitimate landowners in places where land ownership is lucrative (such as near mine sites), and having access to large sums of cash to be used for bride-price payments and other key exchange transactions. Unable to achieve community (much less global) expectations, many of today's young men feel unfairly placed in social-psychic pressure cookers of impossible expectations, feelings that may contribute to acts of compensatory violence as well as violent efforts to force 
others (such as parents, more prosperous siblings and other relatives) to help them achieve social manhood. The introduction and wide-spread use of guns in parts of PNG has exacerbated the situation (Dinnen and Thompson 2004: 2), with guns being one more thing that ambitious or frustrated young men needalong with gang membership and crime (Goddard 2005) - to succeed in today's gift economy and to achieve or hold onto a measure of prestige and manhood.

In an overview of men and masculinities in PNG, Richard Eves notes that while violence is not everywhere condoned there does seem to be an emergence of an almost global masculine ethos which sees violence as a legitimate means to an end (2006: 15). He further notes that men's violence against women should be situated within a larger context of power relations (2006: 37), and that keeping women in their place is a prevailing characteristic of gender relations in PNG. Again I would argue-along with Macintyre and most of the authors in this volume - against any simplistic notion that 'keeping women in their place' is a prevailing characteristic of gender relations in PNG. Rather, I would argue that it is more fruitful to see the encompassment of young men's ambitions and struggles within changing cultural-economic matrices and global-local realities such as the one I describe below; one in which young Gende women may well be encompassed within a bride-price system and male authority but also one in which there are both traditional and new ways for women to succeed in having their way (and sometimes thwarting men's ambitions) without resorting to the dangers of prostitution and rebellion of Holly Wardlow's Wayward Women (2006). Among the Gende - as with people everywhere-males and females live (and often are caught) in webs of relationships that change over time. Understanding what those webs are composed of and how they change goes far in explaining not only men's violence against women but also men's violence against other men and women's violence against both men and other women (an often overlooked component of gender violence).

Finally, in attempting to understand the complexities of engendered violence, it is worthwhile touching on issues of 'morality' and 'desire'. In The Making of Global and Local Modernities in Melanesia (Robbins and Wardlow 2005), the authors examine Marshall Sahlins' assertions on continuity and discontinuity in culture change. Drawing on a wealth of ethnographic data and individual situations, the authors expand on Sahlins' useful but simplistic premises that indigenous categories shape people's understanding of novel experienceshence his concept of develop-man - and that radical cultural change-and 'development' - only occurs in the face of cultural humiliation (see Sahlins 2005, 1992). As with the Chambri middle-class (Errington and Gewertz 2005), some Gende are masters in both develop-man and 'development', managing their affairs with others in keeping with Gende kastam at the same time as they build and sustain successful commercial enterprises. In the Gende case, questions arise 
as to just how well such 'mastery' is tolerated by other Gende and whether or not 'humiliation' is a necessary factor in change and if so what kinds of change. Many Gende have suffered grave humiliation in the decades since first contact with Europeans in 1932, but degrees of, reactions to and choices arising from past humiliation differ according to many factors, not the least of which are age and gender. Unfortunately, what appears to be not in question (see Filer and Macintyre 2006; Jorgensen 2006) is that past and present choices made with the best intentions of develop-man (or develop-woman) will not save the Gende from the inequalities and violence commonly associated with large mining operations (see also Banks 1999).

\section{Troubled masculinities}

When I first did fieldwork with the Gende, some fifty years after they began leaving home to work in other parts of New Guinea, many Gende men were asking themselves whether they were 'pigs' or 'men', and if they were 'men', why was it that 'money' bossed their every move rather than it being they who bossed money as their ancestors had bossed pigs? Ever since western goods and cash were accepted into the Gende exchange system, their uneven distribution has been a factor in migration. In 1982 and 1983, disparities in wealth and the ability to participate in the exchange system had become so vast that it was no longer possible for either the Gende or me to describe most migration as voluntary. While it can be interpreted as a problem of inequality, the Gendeand especially Gende males - saw it as a question of masculine identity (Zimmer 1984).

Like most Melanesians, the Gende are organised on the basis of a complex system of reciprocity and competitive exchange, which mediates kinship, marriage, land, and personal and gendered identities. Within this system, individuals reveal themselves to be more or less 'good' and 'human' on the strength of their exchange performances relative to competitors both within and outside their clan. Men who are active in promoting the affairs of their clan are known as Big Men (G: wana nambaio). Big Men often have two or more wives to assist them in buying brides for younger men, giving obligatory presentations to children's matrilateral kin, redeeming land which is lost to non-clan members, and ensuring the physical and spiritual well-being of clan members by sponsoring pig feasts and giving away huge amounts of pork and now cash to other clans.

Lesser men do the same things as Big Men, but on a smaller scale. The lowest form of men are 'rubbish men'. Lazy or too weak to attract wives, they have little wealth to invest in their clan, and must work like 'women' in the service of men. While women may achieve a full and powerful humanity and even a 
certain independence in Gende society, calling a man a 'woman' is an insult. Traditionally, women, like pigs, move between clans. Men who cannot compete or fulfil their exchange obligations are in danger of making 'women' or 'pigs' of themselves, losing their children (if they are married and have them) to their wives' clans or to other men (like so many pigs) and in some cases being cast out of village society.

Over the years, migration and economic inequality have had a considerable impact on the marriage chances and conjugal relations of over three generations of Gende men and women (Rosi and Zimmer-Tamakoshi 1993; ZimmerTamakoshi 1993a and b, 1996, 1997c, 1998, 2001). While women have had their share of suffering and challenge, one of the most dramatic impacts was the bachelorisation of Gende society (Zimmer-Tamakoshi 1993a), a process that until very recently showed no sign of easing (Zimmer-Tamakoshi 2001). As late as the 1990s there was a preponderance of unmarried males in their late twenties and thirties in both villages and town and a large number of young Gende women who had married non-Gende husbands who were able to pay the higher bride prices being asked for them as a means of helping their brothers attract wives.

Traditionally, older men and women arranged marriages for their sons and daughters and — with the help of relatives and ambitious Big Men (and women)gathered the pigs and other valuables given as bride price to a girl's family. Young men and women proved themselves worthy of support in the context of male and female initiation and puberty rituals and in their willingness to work hard so as to one day repay their elders for their efforts on their behalf. The size of the bride price reflected on both the young husband and wife as they were expected to eventually redeem the bride price - a practice known as tupoi (G: returning the pigs) - as well as repay whatever support they received in paying obligatory payments to the wife's clan. As bride prices began to include cash and other non-traditional valuables, young men were under pressure to earn money to assist their parents in accumulating bride prices for them. As local developments were patchy and unreliable sources of income, many young Gende were forced to migrate and take their chances finding a job. Differences in education and success in finding well-paid employment began to translate into some young men receiving all the attention (i.e. bride-price support and land rights) while others remained unmarried, in some cases labouring on their wealthier clan brothers' lands, in others living precariously in town. From the 1970s into the 1990s, as many as one half of Gende men between the ages of eighteen and forty-five were living in towns far distant from their home villages.

Women constituted a smaller proportion of the absentees as many young and middle-aged couples split their residence between town and village. While the wives of prosperous migrants contended with their husband's economic independence and sometimes their infidelities and violence, village women and 
women living in peri-urban settlements were still able to achieve some ideals of womanhood by raising pigs and tending well the incomes of less-prosperous husbands (Zimmer-Tamakoshi 1998). For young (and not-so young) bachelors, however, the situation was dire.

Within the past fifteen years, two foreign mining companies have begun what look to become highly profitable mining operations on Gende lands. One- best known as Ramu Nickel and run by the Chinese Metallurgical Construction Corporation (MCC) since 2005 - is located in the forested hills and low mountains south of the Ramu plains in southern Madang Province. In the past this area was used by the Gende primarily for hunting and male initiation. In 1962, lateritic nickel was discovered at Kurumbukare and throughout the sixties and seventies a succession of companies held exploration titles to the Kurumbukare prospect. During the 1980s, exploration moved to the alluvial chromite deposits just north of Kurumbukare (near Daunangare village) but with improving nickel prices exploration resumed at Kurumbukare in 1989 and continued through the early 1990s.

In 1995, Highlands Gold (later known as Highlands Pacific) hired me to do a genealogical survey of Gende and Ramu peoples living in the area as part of a pre-feasibility study. Most of the people included in the survey had only recently moved in to the area to take advantage of potential developments. As the intermittent exploration at Kurumbukare throughout three decades had mirrored the same on and off again exploration and work at the Yandera copper prospect, many Gende 'landowners' had a hard time deciding where they should be investing their greatest efforts - at either Yandera or Kurumbukare. As I wrote in 2001 (and earlier in 1997b and 1997d), I was as first caught off guard by the wholesale 'ancestral gerrymandering' I witnessed at Kurumbukare and Daunangare village in 1995 and again in 2000 on a revisit. By participating in traditional kwiagi and other exchanges, alleged landowners at Ramu Nickel were negotiating new and old clan identities. Some of the alleged landowners were claiming membership (or rights on behalf of their children) in more than one clan in order to retain ties in Yandera as well as Kurumbukare - a legitimate but expensive process involving investing pigs and cash in both one's own and a second clan (most often one's wife's clan). Others, less able or unwilling to spread resources so far, denied membership in Yandera clans claiming I had got it all wrong during my earlier fieldwork there and that I was confusing their wives' clan membership with theirs (interestingly, most of these same individuals came rushing back to Yandera in 2007 to reassert land claims there with the arrival of Marengo Mining).

By the year 2000, initial cash payments had been distributed by Ramu Nickel to leading landowners and male heads of family at Kurumbukare. While the foreign concepts of 'landowner' and 'family head' do not fit Gende social 
reality in which hard-working women of renown can invest in land and speak for their family, Gende men and women see themselves as forced to accept western concepts if they are to receive compensation for their land. The results of this masculine-marked 'development', however, generated a wave of second marriages and domestic violence as older men spent their money and were banking on future compensation payments to fulfil bride prices for new wives. Older wives were angry not only because their husbands left them in the bush to tend gardens while the husbands were in Madang with their new wives, but also because the men were not helping their unmarried sons get wives of their own. All of this was generating inter-generational violence as well as sorcery accusations and physical violence against the older men and in some cases their younger brides. After my 2000 visit, email from Gende who were closer to the situation than I suggested that lethal violence and sorcery accusations were increasing as young men physically attacked their fathers and uncles or accused them (and sometimes their new brides) of sorcery. As one of the cases of young men's violence described below demonstrates, accusing someone of sorcery may be a convenient excuse for killing them and then demanding compensation (or land rights) for 'ridding the village' of the threat of further sorcery. Surprisingly little of the violence described here has ever made it into court, but the Gende's situation begs comparison with Philip Gibb's recent analysis of Simbu sorcery accusations (Gibbs 2010 and Ch. 3).

The other, most recent mining venture in Gende territory is run by the small Australian company Marengo Mining Limited. Marengo's base camp is located adjacent to Yandera village, the location of much of my early fieldwork with the Gende. In 2005, the same year that the Chinese Metallurgical Construction Corporation took over the development of the Ramu Nickel Project, Marengo Mining became involved with the Yandera project. In 2006, Marengo moved from 50 to 100 per cent ownership of the project and in May commenced drilling. The Yandera porphyry system contains one of the largest undeveloped porphyry copper-molybdenum deposits in the southwest Pacific region. For many people living in and around the project, the hope is that decades of frustration over the absence of any significant development are at an end.

In 2007, as part of the required feasibility studies begun by Marengo in July 2007, I and a team of four assistants carried out a social assessment and census of the entire Yandera community including both residents and absentees. We collected 227 household interviews, mapped Yandera village and its garden settlements, and took family photos of the entire village as part of the census data. As I discussed earlier, my analysis of this data showed that - at least for the moment - Yandera was virtually bachelor-free as men were either earning money by working for Marengo or winning it in card games with Marengo employees (and their families). It was also virtually lacking in older men, there 
were many confident older women raising pigs for sons' bride prices and kwiagi for their deceased husbands, and there were many subdued younger women pondering their husbands' polygyny and assumption of superiority over them in the context of mining's inevitable gender-biased plenitude (ZimmerTamakoshi 2008a).

In 2008, the team and I extended our census to include a number of Gende villages populated by Gegeru clans (former lineages of the old Gegeru clan) and a number of closely-related clans that I refer to here as 'Karizoko' (Karasokara is the place name of the largest of the Karizoko villages). The Gegeru villages we surveyed-Mangiai, Karamuke, Mokinangi, Kindakevi and Mondomoare populated by families who constitute many of the major landowners at the Ramu Nickel prospect (as well as in the vicinity of their home villages) and most households have relatives working at Ramu Nickel. Now that Marengo is drilling in their territory and there is speculation that Mangiai may become the 'company town' (as opposed to Yandera or Bundi), many Gegeru families who have been away at Ramu or Madang are now returning to stake their claims. Tensions are high as families and individual family members argue over who retains land rights in the village after many family members have been away for years and some have not maintained active exchange relations relevant to the land in question (a reprise of the situation at Kurumbukare in the 1990s when claimants there argued over who had or had not maintained land rights during decades of disinterest in the then largely uninhabited rainforest). The outcomes of my research also show that at least since the early 1990s and even before, Gegeru peoples have been inter-marrying with members of other Gegeru clans as opposed to making marital alliances with their old allies in Yandera and elsewhere. This redirected sociability has been one way of limiting ownership of Kurumbukare lands (and related compensation payments) to Gegeru clansmen and clanswomen. Enabling this trend, divorce has been a more frequent occurrence among the Gegeru population in recent years as Gegeru men and women have shed non-Gegeru spouses in preference for second marriages with closely related Gegeru clan members. A second factor underlying this turning inwards seems to be a desire of many to forego the overlarge bride prices other Gende clans have been asking from the fairly prosperous Gegeru clans. With two mining companies interested in their lands, the Gegerus are in the arguably enviable position of being able to bargain over how and where they will work and sell their resources. An article in the National, 'Mine Shuts Down' (28 August 2008: 1) reported that workers at Kurumbukare were on strike demanding pay raises and demanding the Madang government and the China Metallurgical Construction Company pay heed to their grievances over 'poor working conditions'. How all of these new developments are affecting gender and inter-generational relations will be addressed in the next section. Suffice to say that lower bride prices give Gegeru women more opportunity to pay 
back their bride price through tupoi and to achieve a more equitable position in their marriages. This gender equity is also supported by brothers and sisters marrying nearby landowners and thus consolidating rights to large tracts of land (newly valuable because of the minerals it contains).

After completing the Gegeru census, the team and I moved on to a set of settlements - Karasokara, Ruvutara, Gogobagu, Imuri, Waganogoi, and Duataithat are frequently lumped under the village name 'Karasokara'. The Karizoko and related clans in this area have for generations been enemies of Yandikari peoples (people living in Yandera) as well as Yandera's primary competitors in the large pig kills that were a focal point in the lives of Big Men and Women (see Zimmer-Tamakoshi 1997c). ${ }^{3}$ Since Marengo started up work in 2006, Yandera men have dominated the workforce, demanding that they-and only theyshould be hired. Conflicts between Karasokara people and Yandikaris have increased as a result of the mine with fights between Karasokara and Yandikari youths a frequent occurrence and Karasokara parents afraid to send their children to the local school in Yandera. In 2010 the situation worsened with parents from Karasokara and several other villages complaining that drunken Marengo workers were sexually assaulting young school girls.

Karasokara's social situation was rapidly changing in many ways, and like the Gegeru situation, the changes were resulting in increasing divisions in Gende society. My 2008 census of the Karasokara villages revealed that while some Karasokara men had waited for decades - along with other Gende-for the Yandera and Kurumbukare prospects to fulfil promises to usher in prosperity for all, bolster threatened masculinities and end the loss of so many marriageable women to non-Gende men, many had not. Over the years, not only had many Karasokara women married Simbu husbands but their brothers were marrying Simbus as well, most moving to the other side of the mountains to live with their Simbu in-laws. Few of these transplanted Gende men had more than one wife but with the help of their sisters and Simbu brothers-in-law they had carved out prosperous livings raising coffee and vegetables and selling them to markets more easily accessible because of the better network of roads on the Simbu side of the mountains.

In 2008, Marengo Mining surprised everyone by expanding their drilling operations into Karasokara clan territory. Every time the core samples showed evidence of copper and molybdenum near Waganogo village, Karasokara clansmen celebrated with dancing and singing. On Sunday 8 June 2008, the people at Waganogoi hosted a pig kill at which they killed over thirty pigs

3 Although rare, Gende have referred to some women as ana nambaio or Big Women. Women who are actively engaged in the Gende exchange system and generous to others are more commonly referred to as ana mogeri or good women. In exceptional cases they are referred to as ana mogeri yonua (very good women) or ana nambaio. 
and gave one very large pig — subsequently named Napoleon - to the Marengo project manager. Most of the cooked pork and pigs were given to allies and inlaws, thereby excluding much of Yandera's population. Now that they too have the possibility of mining in their territory, the Karasokara people are demanding that only they - and certainly no Yandakaris - work at drill sites and camps in their territory.

Unfortunately for those Karasokara people living in the village-as opposed to those who have migrated out - their Simbu in-laws and local absentees are now showing up in the villages and demanding to be part of the expected bonanza. Many absentees have been hard put to pay their Simbu in-laws the higher bride prices demanded for Simbu brides and so are under pressure themselves to make sure that they too are considered fully-invested landowners back in their home villages. Conflicts between parents and brothers of absentees broke out on several occasions as my team and I carried out our interviews or I took my photos for the census record. While I was interested in getting full coverage of potential landowners, local citizens were beginning their battles with one another over who should or should not be included. Eventually this will be the focus of landowner associations but at that moment there was a panic about being included (or not). Older informants worked late into the night to include the names and families of daughters married to Simbu husbands as they fully expected that the daughters would return home to be compensated for land.

While Karasokara women married to Simbu husbands may be experiencing a new importance within their families and marriages, women in Yandera were beginning to voice their dissatisfaction over the general lack of employment for women within the mining operation. Washer women were already divided into several shifts who alternated work weeks. When the daughter of an out-married Yandera woman - who makes a hefty profit selling vegetables raised by Simbu women to the company - started working for Marengo as one of the laundry girls, all hell broke loose and she was driven off by young wives in Yandera village who themselves desired to earn some cash to help balance things between themselves and their employed husbands. Similarly, early on the morning of 24 June 2008, a group of women and children stormed the camp, throwing stones at the security gate and shouting their grievances and obscenities at the men. Several young women in particular were angry that there was no work for them at the camp, wanting the management to fire the camp secretary-who is Gende but whose father is the head of one of the Kurumbukare landowners' associations and who the young women said didn't need the work as much as they. They were especially angry with the daughter of an absentee who had arrived at the camp to do a practicum. The angry group drove her away and, on another day, physically attacked and bit the camp secretary. These angry demonstrations were in sharp contrast to young women's apparent biding their 
time in 2007. In 2010 I heard stories that women were being further oppressed by some Community Affairs officers (all male) demanding-and gettingsizeable kick-backs from women in order that the women be included in the list of laundry workers.

The above conflicts over work opportunities do not by any means exhaust women's conflicts with one another. Some of the most heated and long-lasting are, ostensibly, over men. For the remainder of this paper, I will examine some of the cultural and economic underpinnings of the escalating violence within the Gende community, focusing primarily on violence and men's contradictory experiences of power but also looking at the impact of changing masculinities on Gende women's strategies and well-being. I end the paper with some initial reflections on engendering solutions to male violence.

\section{Violence and men's contradictory experiences of power}

Melanesia has long been an important region for gender studies with its diverse concepts of masculine social, bodily and sexual development over the life cycle (Knauft 1999; Strathern 1988) and yet there are few comprehensive effortssuch as Jolly (2000), Richard Eves (2006) and John Taylor's collection (2008) — on how changing masculinities play into gender violence. In 1990, I published two papers that together investigate both traditional and contemporary attitudes and circumstances associated with young men's violent behaviour towards women and their elders (Zimmer 1990a and b). Both articles demonstrate the pivotal role of young men's access to crucial resources for attaining social manhood and the contradictory messages and experiences surrounding young men's coming of age. In 'Sexual Exploitation and Male Dominance in PNG' (1990b), I argued that 'rape, prostitution, and pornography are by no means new phenomena in Papua New Guinea' (p. 225). Citing ethnographic accounts as well as more recent cases reported in the Post-Courier, I argued further that 'while poverty or a sense of political injustice may motivate individuals to strike out at the society that has failed them, the form rebellion takes is culturally patterned' (p. 258). In many PNG societies, the basis for the subordination of women and the exploitation and manipulation of their sexuality was older men's control of most economic resources and male ideologies which portrayed women as dangerous, inferior, and untrustworthy creatures who were to be feared, kept under control, and avoided whenever possible. Such ideologies were directed primarily at young men as a means of keeping them away from women until the young men's elders felt it was time for them to marry. At the same time, the use of rape and physical violence to control 'unruly' women was commonplace and young men were 
sometimes encouraged to participate in the rapes and sexual abuse of women. While older men no longer control all economic resources and having a wife who raises pigs is no longer an absolute necessity for men of ambition, many young men are still dependent on their elders for bride-price support and access to land rights (which are especially key in areas of new development). For young men who opt (or are forced) to stay in town, unmarried and unrespectable by their parents' standards, joining gangs of other young men who make their own rules and standards is an attractive, albeit ultimately dead-end, proposition. In town, new ideas of women's inferiority and men's right to dominate them have been grafted onto the old, and definitions of masculinity are more free-floating and no longer under the control of the larger society young men act in.

A chilling example of how some young men justify their actions is the young urban gang-member I quoted in 'Wild Pigs and Dog Men' (1997e: 569) who back in 1982 bragged to me about kidnapping and raping young women. In response to my obvious shock he said, 'They liked it! It was like it is in a James Bond movie - sexy! The woman fights with James Bond and tries to kill him and then he forces her to have sex with him and she is his woman from then on. Sometimes he kills her if she is a really bad woman.' In reply to my question as to whether or not he had killed anyone, he said he had killed the one married woman because he feared she would tell her husband that he raped her (which he denied, insisting that it wasn't rape and that 'She liked it! I'm sexy!') In the past such a woman may have been safe - or at least avenged by husband or brother. Today such rapists must first be caught and then tried in a court system that is often too lenient or indifferent (see Hukula, Ch. 6; Zorn, Ch. 5). At the time, this young man had returned home to Yandera village to take advantage of a big pig feast and all the associated wealth (including cash) circulating among participants and in local card games. He and several other youths went on a month-long robbery spree as well as assaulting girls and women and mocking older men's frustrated threats of bodily harm to the offenders-frustrated because older men are no longer free to axe or bludgeon someone they desire to be rid of.

In another article published in 1990, on 'Conflict and Violence in Gende Society' (1990a), I focused on older persons as victims, trouble-makers and perpetrators of violence. Several key points in that article were (1) in efforts to balance their own exchange obligations, older persons favoured more prosperous migrants as exchange partners, often at the expense of their own sons; (2) delaying sons' marriages and/or withholding clear access to garden lands was a constant sore point between the generations; and (3) often - but not always - tensions were taken out on sisters or daughters with brothers and parents pressuring the girls to marry for larger bride prices regardless of a girl's personal choice of mate. Not every young man was violent, of course. Some who helped their mothers 
raise bride-price pigs also participated in high-stakes card games which enabled them to 'play at being men' (Zimmer 1987). A few swallowed their pride and worked on land belonging to wealthier clan brothers, sharing some of the pigs they raised with the absentee landowner (along with the help of their mothers and sisters or in a very few cases their young wives). This form of rent to the landlord practically guaranteed that such young men would not become renowned Big Men (since it made prosperous migrants even wealthier and more influential than they already were). But for some young men, this was preferable to living in town and becoming part of a gang of thugs or living off the kindness of others indefinitely.

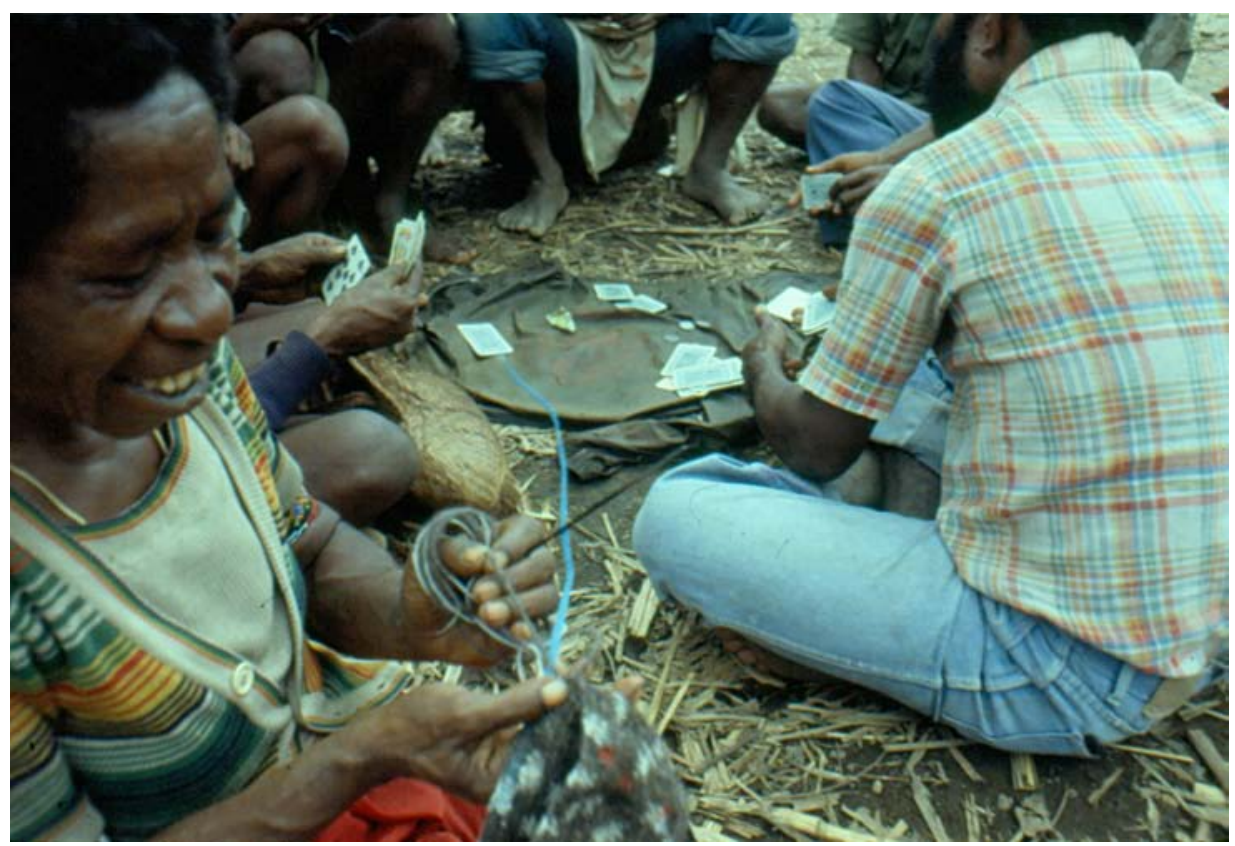

Figure 6. Young men playing cards in Yandera in 1982.

Photograph by Laura Zimmer and courtesy of Laura Zimmer-Tamakoshi.

While violence against their elders was not common during the first twenty years I observed the Gende, there were incidents and even deaths (Zimmer 1990a). The relationship with the most conflict was that between father and sons. Sons expect fathers to help with land and bride-price support and to side with them in disputes involving other persons. While such support also comes from other persons, there can be quite a lot of bitterness when a significant amount of help is not forthcoming from a man's biological father. The same holds true for fathers who expect to be taken care of by their sons in later years. 
A son's divided loyalties may become a source of irritation and recrimination and trigger violence, usually a few blows and the destruction of property and often the diversion of tensions onto a third party.

Relations between a father-in-law and his daughter's husband are also sources of conflict and violence and can pull in all sorts of aggrieved parties, including disappointed sons who pressure their fathers and sisters to end marriages that have failed to bring in bride prices large enough for them to acquire brides of their own. Acts of violence involving mothers and their children are rare, as women find many ways of helping children, be it in town or village, tending grandchildren while adult children work or themselves working indefatigably raising pigs. Relations between women and their daughters-in-law are less amicable, at least until the younger women have made tupoi (that is redeemed the bride price that was paid for them).

That the Gende have been and are a people under enormous stress became painfully clear in early 1991 when a leading Big Man was killed by a younger clan member in a fight over land (Zimmer-Tamakoshi 1997c). The argument began in 1982 when the younger man returned from town with his wife. He discovered that land that he had assumed was his, on which to plant gardens and coffee, was being used by one of the Big Man's three wives. The Big Man, Ruge Angiva, argued that he had been a large contributor to the deceased owner's death payments (kwiagi) in contrast to the returned migrant who had been away for years and contributed little to village exchanges. He graciously offered to allow the younger couple to use some of the land in question in return for a pig or two. This infuriated the younger man whose anger simmered and erupted periodically over the next nine years until he and another man got into an argument with the older man, hitting Ruge until he fell to the ground and then kicking him to death. That other men, including the Big Man's sons, watched without intervening suggests a great deal of resentment on the part of young men. During a visit in 1994, there was the sense that there were no longer any leaders who could command the respect of younger men and manage capitalist development and all its attendant inequalities for the good of the people.

In this case and others, it became clear that one of the biggest contradictions, or paradoxes, young Gende men struggle with is that despite patriarchal assertions of male superiority, traditionally Gende women can achieve great influence and even power through their participation in the Gende exchange system and young men and women were (and in many cases still are) as dependent on women's help as they are on men's. In 'Empowered Women' (Zimmer-Tamakoshi 1997a), I showed how Gende women, by redeeming their bride prices (tupoi) and helping husbands fulfil child wealth (TP: bun pe; G: wana yamindikai inime, a Gende figure of speech meaning paying 'those who gave bones' to the child, i.e. mother's clan) obligations to the women's families, achieved a 
measure of independence and respect within their own and their husbands' clans. At this point in their lives, usually middle-aged and no longer bearing children, ambitious women were free to invest the pigs they raised pretty much as they wished and even to leave unruly husbands (a disaster for most men). Such women never had a lack of male helpers as there were always young men or ambitious brothers or Big Men who would help them clear gardens so the women could raise many pigs.

In recent times, with cash part of every bride price and every other form of exchange, it is more difficult for most women to redeem their bride prices much less catch up in the exchange cycle. Even so, most women contribute significantly to their tupoi obligations, giving pigs as well as cash they have earned from selling pigs to others. Ordinary women still manage to wield a certain amount of influence over others as I have shown in past writing. Older women were crucial in bringing about the closing of a large cardamom plantation that threatened their control over young women and did little to help them keep up with inflationary exchange payments (Zimmer-Tamakoshi 1996). Women living in a small settlement of Gende on the outskirts of Goroka managed their husbands' fairly low incomes in ways that allowed such couples to raise their children in urban environments (with better education and health care), while at the same time they held on to land rights in their home villages by raising pigs and nurturing cash through good financial management of their less-prosperous husbands' incomes (Zimmer-Tamakoshi 1998). Without their wives, these men would be nothing, which the wives were quick to remind their husbands should they come home drunk or try to fool around.

While young men sometimes chafe at all this feminine control, perhaps most annoying is the unusual success of some women, particularly the extremely successful entrepreneurial daughter of the aforementioned Big Man, Ruge Angiva. Towards the end of his life, as local development seemed more and more of an impossibility, Ruge's daughter pulled her business ventures out of Yandera village, and he urged his followers to follow her to her new business location. Then the Big Man began calling himself her boi. In using a negative colonial term to describe himself, the Big Man was both attempting to manipulate his daughter into giving him a more respectable position in her business enterprises and expressing his own despair over his lack of control of the bigger process. Not wanting to be anyone's boi, much less that of a fairly young woman, the Big Man's killers were quite clear in their deadly intentions.

With cash now pouring into the Gende exchange system in decidedly unequal ways, there are unfortunately plentiful opportunities to examine violence of all kinds among the Gende. Based on what I have witnessed during my most recent field seasons (2007, 2008, 2009, 2010 and 2011), older men no longer have the upper hand at Yandera, but they do in the Gegeru home villages we surveyed. 
How long that will last, however, remains to be seen as the following incident demonstrates. Towards the end of my 2008 fieldwork I was in Madang working on an interim report for Marengo Mining and interviewing Ramu Nickel landowners when I heard news of a vicious killing in Kindakevi village. The unmarried nephews of one Gegeru landowner we had interviewed had axed their uncle to death, claiming he was a sorcerer. According to my informants, few people believed in the accusation, stating that the nephews had been angry with their uncle for claiming ownership of both his own and their deceased father's land. To prove they were acting on a sincere belief that their uncle was a sorcerer, the youths chopped up his body and burnt it along with his house. Angry villagers threatened the young men, calling them good-for-nothing murderers. The youths fled to Madang to avoid arrest. In response, close kin of the murdered man then bound up several women (including the young men's mother), threatening to bury them alive if the killers did not return to face their accusers and pay compensation for the murder. More than a month after this event, the youths had not returned to Kindakevi, there was no serious police action taken (there are virtually no police at Bundi station since most had moved down to Brahman to be closer to Ramu Nickel) and the women were shaken but unharmed. The murder is not forgotten, but many Gegeru 'landowners' are now nervous about the possibility of more violence and wondering if old customs surrounding land ownership will prevail in an extremely tense, virtually lawless and greed-inducing situation.

The above violence shows how young men's frustrations and need to acquire (or control) wealth in order to be 'real men' can lead to violence when older men and women seemingly, or in actuality, disregard their needs. It also demonstrates how the violence can spread to include the taking of hostages and threats of reprisals against female relatives of the accused. I would claim that all of this violence and threats of violence-young men against older men, men against women - is best described as 'engendered' violence because the root causes are gender-related: a desire to achieve manhood through marriage, the threat of losing one's mother and best bride price supporter. The new lawlessness suggests an individual man or woman can take things into their own hands and wrongly deprive another of their life in order to gain something of newlyheightened value.

After a season of quiet among the young wives at Yandera in 2007, their outbursts in 2008 suggested that Gende women were not going down without a fight. I was also not surprised when one very angry Gegeru wife and mother of several children arrived at my field home in Mangiai village one evening demanding an interview. Abandoned by her Kindakevi husband for another woman, the old wife had taken her family to her home village where she was planting gardens and raising pigs to complete her tupoi obligations to her Kindakevi in-laws. 
Her husband was living in another Gegeru village along with his new wife, a Mondomo woman who had recently left her Yandera husband-who has a well-paying job at Marengo-because he was too bik het (TP: big-headed). The cast-off wife was angry that her Kindakevi in-laws had not included her and her children in the interview for the house she and her husband had shared. Given that she had repaid much of her bride price to them and that she had always supported her husband's clan's exchange events, she and her childrenincluding her teenage son-had every right to be angry at their attempt to erase them from the record. That her Kindakevi in-laws favoured the new wife, however, was not surprising for the land surrounding her home village of Mondomo is also under consideration by Marengo whereas the first wife's is not.

\section{Conclusion: Engendering solutions to male violence}

In addition to documenting violence and its probable causes, it is essential to explore solutions. The violence I have described is engendered. It rises out of tensions within the gendered matrix of Gende social relations, as well as the larger, equally - albeit differently-gendered systems within which the Gende are citizens and workers. I expect the most useful solutions will also be structurally gendered. In her work exploring Kup women's efforts to address issues of tribal fighting and violence against women and children in the Kup Sub-District of Simbu Province, Sarah Garap (2004) makes a distinction between two forms of violence, calling the one 'tribal' and the other 'gendered'. By separating tribe/community and 'women and children', however, Garap misses the point that the Kup community is pervasively gendered. What are the tribes fighting about if not the impact social inequalities have on the have-nots? And what is it they have-not? Women, land (without which one does not get or keep a wife) and cash. The artificial separation of tribal fighting from 'gendered' violence is also evident in Garap's statement that women and young girls are prime targets for vengeance to shame and provoke the enemy (2004: 5). Without unravelling the complete matrix of engendered 'tribal' relations - such as relations between older and younger men and how these affect both older and younger men's access to (or better yet, relations with) women and powerone misses out on fuller explanations for violence against Kup women and children. Just as relatives of the murdered Kindakevi man threatened vengeance against female relatives of the killers in order to cut them off from the valuable resources the women represent for the young men, so too is it logical that 'tribal' enemies would strike against the enemy's wives and children considering their 
culturally and economically high value to male relatives. Other attempts to connect 'domestic' and 'public' violence include Jolly's Epilogue to Reflections on Violence in Melanesia (2000) (see also Jolly's Introduction, this volume).

While it is important that women are taking a visible stance against violence and destruction, Kup women's objectives and strategies are not focused on how to better deal with young men's violent behaviour other than to get them to surrender their weapons and receive amnesty from the government, to publicly apologise and to promise not to involve themselves in any 'bad habits and criminal behaviour' again (2004: 8). Garap describes some of the short-term euphoria over temporary halts in tribal fighting but goes on to conclude that 'there are no quick fix solutions to the many socio-economic and political problems of Papua New Guinea' (2004: 12). Indeed! Until young men (and young women) are included within our models of 'community' as being something other than merely trouble-makers, and until we take their social needs seriously, there will be no peace. Community-based initiatives require the input and support of all segments of society along with more fine-grained analyses of local social relations. In an article on women in PNG's village courts, Michael Goddard argues that women use village courts more than is commonly recognised and are less put-upon because of it (2004). That this may not be as effective as Goddard supposes is evident in the extreme measures taken by Wardlow's 'wayward women' to assert their value and independence from 'the system', however negatively expressed (2006). In this chapter I have explored the notion that we need to pay greater attention to young men's social needs than we have in the past and be wary of conflating 'gender' with 'woman' and perpetuating stereotypes regarding who is or who is not affected negatively by changes brought about by development and globalisation (Zimmer-Tamakoshi 2008b).

Paying attention to the voices of different segments of Gende society over the years-including those of both bachelors and young women-I have documented in some detail how marriage and the bride-price system have proven to be minefields in one way or another for most Gende (e.g. Zimmer 1984, 1987 and Zimmer-Tamakoshi 1993a, 1996). Some societies, such as the PNG fringe-highlanders studied by James G. Flanagan (1997) and Susan M. Pflanz-Cook (1993) have, at least in the past, reined in their bride-price systems preferring balance in inter-group relations and exchange, resisting the outright sale of sisters and other women documented by myself (Zimmer-Tamakoshi 1993a) and Dan Jorgensen for the Telefolmin (1993).

Any community-based solutions to gender violence and other gender-related violence such as that occurring between the generations must address the possibility that the bride-price system ought to be curtailed and cut off from local and global market forces (as was reported for the Tolai decades ago, see 
Epstein 1968: 93, 150). As I have shown here and elsewhere, the Gende's bride-price system includes the possibility for women to acquire prestige and influence through tupoi. I would not therefore suggest the eradication of the Gende's exchange system (Gende women still use tupoi as an expression of their involvement and importance in Gende society). It would be better if it were reined in and some thought given to a more equitable distribution of household compensation monies by both the government and those in charge of the distribution of wealth from such gender-biased industries as the mining industry. In such an ideal scenario, the wealth of the community would be directed towards males and females of all ages. Nor am I suggesting that the young killers in Kindakevi be given what they have not worked for. Rather, landowner associations and all legitimate claimants, with the support and oversight by the government, should be joint recipients of any compensation, thereby allowing a greater range of actors to participate in locally desired social relations. While it seems unlikely that the flush former bachelors of Yandera are going to change their competitive exchange system any time soon, at least some Gende, the Gegerus, for example, have managed their marriages in a way that reduces bride price and ensures that land rights and compensation stay closer to home. How much compensation actually will end up in the hands of Gegeru women remains to be seen. With lower bride prices, they have more of a chance to fulfil their tupoi obligations to in-laws and therefore more of a voice in their communities. But unless women as well as men serve on local landowner associations, it is unlikely that men will pay as much attention to women as they should. 'Troubled masculinities' are not a thing of the past for Gende males and even men who are now out of the woods are not likely to forget the sting of past humiliations. Holding fast to their newfound gains, Gende men may bring about a form of 'development' that is no development at all: unbalanced, full of new conflicts, and humiliating for both women and men who do not benefit from the current development 'opportunities'.

\section{References}

Banks, Glenn, 1999. The economic impact of the mine. In Dilemmas of Development: The Social and Economic Impact of the Porgera Gold Mine 19891994, ed. Colin Filer, 88-127. Canberra: Asia Pacific Press.

Billy, Afu, 2000. Breaking the silence, speaking out truths: domestic violence in Solomon Islands. In Reflections on Violence in Melanesia, ed. Sinclair Dinnen and Allison Ley, 172-77. Sydney: Hawkins Press and Asia Pacific Press. 
Billy, Afu, Hazel Lulei and Jully Sipolo, eds, 1983. 'Mi Mere': Poetry and Prose by Solomon Islands Women Writers. Honiara: University of the South Pacific, Solomon Islands Centre.

Borrey, Anou, 2000. Sexual violence in perspective: the case of Papua New Guinea. In Reflections on Violence in Melanesia, ed. Sinclair Dinnen and Allison Ley, 105-18. Sydney: Hawkins Press and Asia Pacific Press.

Bradley, Christine, 1994. Why male violence against women is a development issue: reflections from Papua New Guinea. In Women and Violence, ed. Miranda Davies, 10-26. London: Zed Books Ltd.

Counts, Dorothy Ayres, Judith K. Brown and Jacquelyn C. Campbell, eds, 1992. Sanctions and Sanctuary: Cultural Perspectives on the Beating of Wives. Boulder: Westview Press.

Coursen-Neff, Zama, 2005. 'Making their own rules': police beatings, rape, and torture of children in Papua New Guinea. Human Rights Watch, 30 August. Online: http://www.hrw.org/en/node/11626/section/1. Accessed 6 April 2011.

Dinnen, Sinclair, 1996. Law, order, and state. In Modern PNG Society, ed. Laura Zimmer-Tamakoshi, 333-50. Kirksville, MO: Thomas Jefferson University Press.

2000. Violence and governance in Melanesia: an introduction. In Reflections on Violence in Melanesia, ed. Sinclair Dinnen and Allison Ley, 1-16. Sydney: Hawkins Press and Asia Pacific Press.

Dinnen, Sinclair and Alison Ley, 2000. Reflections on Violence in Melanesia, Sydney: Hawkins Press and Asia Pacific Press.

Dinnen, Sinclair and Edwina Thompson, 2004. Gender and small arms violence in Papua New Guinea. Discussion Paper 2004/8. State, Society and Governance in Melanesia Project, Research School of Pacific and Asian Studies. Canberra: The Australian National University.

Epstein, T.S., 1968. Capitalism, Primitive and Modern: Some Aspects of Tolai Economic Growth. Canberra: Australian National University Press.

Errington, Frederick and Deborah Gewertz, 2005. On humiliation and class in contemporary Papua New Guinea. In The Making of Global and Local Modernities in Melanesia, ed. Joel Robbins and Holly Wardlow, 163-170. Hampshire: Ashgate Publishing. 
Eves, Richard, 2006. Exploring the Role of Men and Masculinities in Papua New Guinea in the 21st Century: How to address violence in ways that generate empowerment for both men and women. Report for Caritas Australia. Online: http://www.baha.com.pg/downloads/Masculinity \%20and \% 20 Violence\%20in\%20PNG.pdf. Accessed 28 November 2010.

Filer, Colin and Martha Macintyre, 2006. Grass roots and deep holes: community responses to mining in Melanesia. In Melanesian Mining, Modernities: Past, Present, and Future, ed. Paige West and Martha Macintyre. Special issue of The Contemporary Pacific 18(2): 215-32. Honolulu: University of Hawai'i Press.

Flanagan, James G., 1997. Exchanging sisters is not a game. In Social Organization and Cultural Aesthetics: Essays in Honor of William H. Davenport, ed. William W. Donner and James G. Flanagan, 61-72. Lanham, MD: University Press of America, Inc.

Garap, Sarah, 2000. Struggles of women and girls - Simbu Province, Papua New Guinea. In Reflections on Violence in Melanesia, ed. Sinclair Dinnen and Allison Ley, 159-71. Sydney: Hawkins Press and Asia Pacific Press.

2004. Kup women for peace: women taking action to build peace and influence community decision-making. Discussion Paper 2004/4. State, Society and Governance in Melanesia Project, Research School of Pacific and Asian Studies. Canberra: The Australian National University.

Gibbs, Philip, 2010. Witchkilling and engendered violence in Simbu. Catalyst 40(1): 24-64.

Goddard, Michael, 2004. Women in Papua New Guinea's village courts. Discussion Paper 2004/3. State, Society and Governance in Melanesia Project, Research School of Pacific and Asian Studies. Canberra: The Australian National University.

2005. The Unseen City: Anthropological Perspectives on Port Moresby, Papua New Guinea. Canberra: Pandanus Books.

Hogan, Evelyn, 1985. Controlling the bodies of women: reading gender ideologies in Papua New Guinea. In Women and Politics in Papua New Guinea, ed. Maev O'Collins et al., 54-71. Working Paper No. 6, Canberra: Department of Political and Social Change, The Australian National University.

Jenkins, Carol (and The National Sex and Reproduction Research Team), 1994. National Study of Sexual and Reproductive Knowledge and Behaviour in Papua New Guinea. Monograph 10. Papua New Guinea Institute of Medical Research. 
Jolly, Margaret, 1994. Women of the Place: Kastom, Colonialism and Gender in Vanuatu. Chur and Reading: Harwood Academic Press.

1997. Woman-nation-state in Vanuatu: women as signs and subjects in the discourses of kastom, modernity and Christianity. In Narratives of Nation in the South Pacific, ed. Ton Otto and Nicholas Thomas, 133-62. Amsterdam: Harwood Academic Publishers.

2000. Further reflections on violence in Melanesia. In Reflections on Violence in Melanesia, ed. Sinclair Dinnen and Allison Ley, 305-24. Sydney: Hawkins Press and Asia Pacific Press.

Jorgensen, Dan, 1993. Money and marriage in Telefolmin: from sister exchange to daughter as trade store. In The Business of Marriage: Transformations in Oceanic Matrimony, ed. Richard A. Marksbury, 57-82. ASAO Monograph No. 14. Pittsburgh: University of Pittsburgh Press.

2006. Hinterland history: the Ok Tedi Mine and its cultural consequences in Telefolmin. In Melanesian Mining, Modernities: Past, Present, and Future, ed. Paige West and Martha Macintyre. Special issue of The Contemporary Pacific 18(2): 233-63. Honolulu: University of Hawai'i Press.

Josephides, Lisette, 1993. Gendered violence in a changing society: the case of urban Papua New Guinea. Journal de la Société des Océanistes 99: 187-96.

Kaufman, Michael, 1994. Men, feminism, and men's contradictory experiences of power. In Theorizing Masculinities, ed. Harry Brod and Michael Kaufman, 59-85. Thousand Oaks, CA: Sage Publications.

1999. The 7 P's of Men's Violence, 1998 Workshop Organised by Save the Children (UK), Kathmandu, Nepal. Printed online in Toronto, Canada, October. Online: http://www.michaelkaufman.com/1999/10/04/the-7-ps-ofmens-violence. Accessed 11 April 2011.

Knauft, Bruce, 1999. From Primitive to Postcolonial in Melanesia and Anthropology. Ann Arbor: The University of Michigan Press.

Macintyre, Martha, 2000. Major issues in law and order affecting women and children. Discussion Paper (1-25 September). Port Moresby: Royal Papua New Guinea Constabulary Development Project Phase III.

Molisa, Grace Mera, 1987. Colonised People. Port Vila, Vanuatu: Blackstone Publications.

1989. Black Stone II. Port Vila, Vanuatu: University of the South Pacific, Vanuatu Centre. 
O'Collins, Maev, 2000. Images of violence in Papua New Guinea. Whose images? Whose reality? In Reflections on Violence in Melanesia, ed. Sinclair Dinnen and Allison Ley, 19-34. Sydney: Hawkins Press and Asia Pacific Press.

Pflanz-Cook, Susan M., 1993. Manga marriage in transition, from 1961 to 1981. In The Business of Marriage: Transformations in Oceanic Matrimony, ed. Richard A. Marksbury, 105-26. ASAO Monograph No. 14. Pittsburgh: University of Pittsburgh Press.

Robbins, Joel and Holly Wardlow, eds, 2005. The Making of Global and Local Modernities in Melanesia: Humiliation, Transformation and the Nature of Cultural Change. Hampshire: Ashgate Publishing.

Rosi, Pamela and Laura Zimmer-Tamakoshi, 1993. Love and marriage among the educated elite in Port Moresby. In The Business of Marriage: Transformations in Oceanic Matrimony, ed. Richard A. Marksbury, 175-204. ASAO Monograph No. 14. Pittsburgh: University of Pittsburgh Press.

Sahlins, Marshall, 2005 [1992]. The economics of develop-man in the Pacific. Reprinted in The Making of Global and Local Modernities in Melanesia, ed. Joel Robbins and Holly Wardlow, 23-42. Hampshire: Ashgate Publishing.

Strathern, Andrew, 1993. Violence and political change in Papua New Guinea. Pacific Studies 16(4): 41-60.

Strathern, Marilyn, 1988. The Gender of the Gift: Problems with Women and Problems with Society in Melanesia. Berkeley: University of California Press.

Taylor, John P., ed., 2008. Changing Pacific Masculinities. Special issue of The Australian Journal of Anthropology 19(2).

Toft, Susan, ed., 1985. Domestic Violence in Papua New Guinea. Monograph No. 3. Law Reform Commission, Papua New Guinea.

1986. Domestic Violence in Urban Papua New Guinea. Occasional Paper No. 19. Law Reform Commission, Papua New Guinea.

Toft, Susan and Susanne Bonnell, eds, 1985. Marriage and Domestic Violence in Rural Papua New Guinea: Results of a Research Project Conducted by the Law Reform Commission and Administrative College of Papua New Guinea. Port Moresby: Papua New Guinea Law Reform Commission.

Wardlow, Holly, 2006. Wayward Women: Sexuality and Agency in a New Guinea Society. Berkeley: University of California Press. 
Zimmer, Laura J., 1984. Pigs, money, migrants, or men? Identity crisis in the Highlands of Papua New Guinea. Paper read at the session on 'Migration' at the 83rd Annual Meeting of the American Anthropological Association in Denver, Colorado, November.

1987. Playing at being men. In Gambling with Cards in Melanesia and Australia, ed. Laura J. Zimmer. Special issue of Oceania 58(1): 22-37.

1990a. Conflict and violence in Gende society: older persons as victims, trouble-makers, and perpetrators. In Domestic Violence in Oceania, ed. Dorothy Counts. Special issue of Pacific Studies 13(3): 205-24.

1990b. Sexual exploitation and male dominance in PNG. In Human Sexuality in Melanesian Cultures. Special issue of Point Series 14: 250-67.

Zimmer-Tamakoshi, Laura, 1993a. Bachelors, spinsters, and 'pamuk meris'. In The Business of Marriage: Transformations in Oceanic Matrimony, ed. Richard A. Marksbury, 83-104. ASAO Monograph No. 14. Pittsburgh: University of Pittsburgh Press.

- 1993b. Nationalism and sexuality in Papua New Guinea. Pacific Studies 16(4): 20-48.

1995. Passion, poetry, and cultural politics in the South Pacific. In The Politics of Culture in the Pacific, ed. Richard Feinberg and Laura ZimmerTamakoshi. Special issue of Ethnology (Spring \& Summer): 113-27.

1996. The women at Kobum Spice Company: tensions in a local age stratification system and the undermining of development. In Women, Age, and Power: The Politics of Age Difference Among Women in Papua New Guinea and Australia, ed. Jeanette Dickerson-Putman. Special issue of Pacific Studies 19(4): 71-98.

1997a. Empowered women. In Social Organization and Cultural Aesthetics: Essays in Honor of William H. Davenport, ed. William W. Donner and James G. Flanagan, 45-60. Lanham: University Press of America, Inc.

1997b. Everyone (or no one) a winner: Gende compensation ethics and practices. In Compensation for Resource Development in Papua New Guinea, ed. Susan Toft, 66-83. Papua New Guinea Law Reform Commission Monograph No. 6. Port Moresby.

1997c. The last big man: development and men's discontents in the Papua New Guinea Highlands. Oceania 68(2): 107-22. 
1997d. When land has a price: ancestral gerrymandering and the resolution of land conflicts at Kurumbukare. In Rights to Land and Resources in Papua New Guinea: Changing and Conflicting Views, ed. Paula Brown and Anton Ploeg. Special issue of Anthropological Forum 7(4): 649-66.

1997e. Wild pigs and dog men: rape and domestic violence as women's issues in Papua New Guinea. In Gender in Cross-Cultural Perspective, ed. Caroline B. Brettell and Carolyn F. Sargent, 538-53. Upper Saddle River: NJ: Prentice-Hall.

1998. Women in town: housewives, homemakers and household managers. In Modern Papua New Guinea, ed. Laura Zimmer-Tamakoshi, 195210. Kirksville, MO: Thomas Jefferson University Press.

2001. Development and ancestral gerrymandering: David Schneider in Papua New Guinea. In The Cultural Analysis of Kinship: The Legacy of David Schneider and Its Implications for Anthropological Relativism, ed. Richard Feinberg and Martyn Ottenheimer, 187-203. Champaign, IL: University of Illinois Press.

2004. Rape and other sexual aggression. In The Encyclopedia of Sex and Gender, ed. Carol R. Ember and Melvin Ember, 230-43. New York: Kluwer.

2006. Uncertain futures, uncertain pasts. Paper presented in working session on Mine Closure in the Pacific: Past Experiences and Anticipated Futures, co-organised by Dan Jorgensen and Glenn Banks. ASAO annual meeting, February, San Diego CA.

2008a. Final Report: 2007 Yandera Survey/Census. Prepared for Marengo Mining Ltd. Perth, Australia.

2008b. It's not about women only. In Pulling the Right Threads: The Ethnographic Life and Legacy of Jane C. Goodale, ed. Laura Zimmer-Tamakoshi and Jeanette Dickerson-Putman, 56-76. Champaign, IL: University of Illinois Press. 